\title{
TEORIAS DA LEI NATURAL: PUFENDORF E ROUSSEAU ${ }^{1}$
}

\author{
Luiz Felipe Netto de Andrade e Silva SAHD ${ }^{2}$
}

- RESUMO: O presente artigo tem como objetivo reconstruir argumentos centrais desenvolvidos por Jean-Jacques Rousseau. Contra Samuel Pufendorf, Rousseau defende que a justiça não é natural. Ele recusa todo compromisso com a lei natural tradicional para voltar à posição de Thomas Hobbes. Ora, no estado originário de natureza, os princípios racionais da lei natural que expõe Pufendorf não podem ser conhecidos, e, por conseguinte, quando puderem ser conhecidos, não serão aplicados por natureza.

- PALAVRAS-CHAVE: lei natural; liberdade; moralidade; sociabilidade.

\section{Introdução}

O tema da lei natural recebe de Rousseau um tratamento conciso, o que deu lugar a uma grande incerteza quanto à posição exata e ao papel assumido por ele no seu pensamento político. ${ }^{3}$ Um amplo debate entre os comentadores visando determinar se o genebrino repudia ou aceita a lei natural comprova a dificuldade para se chegar a uma solução razoável sobre o tema. Rousseau apresenta seus argumentos iniciais no prefácio do Discurso sobre a desigualdade entre os homens, sob a forma de uma refutação condensada

1 Este artigo é uma versão corrigida da comunicação pronunciada no XII Encontro Nacional de Filosofia da ANPOF (GT Filosofia e Direito), em Salvador a 24/10/2006. Agradeço o apoio recebido da Fundação de Amparo à Pesquisa do Estado de Minas Gerais - FAPEMIG.

2 Professor Adjunto do Departamento de Filosofia e do Programa de Pós-Graduação em Filosofia da Universidade Federal de Uberlândia - UFU/MG. Artigo recebido em abr/07 e aprovado em set/07.

3 Há um amplo debate entre os estudiosos para determinar se Rousseau rejeita ou aceita a lei natural. Eis alguns exemplos: Master, 1968, p.76-89, 158-65, 316-22; Hall, 1973, p.25-8; Goldschmidt, 1974, p.133-55; Plattner, 1979, p.104-7. 
e elíptica de "nossos juristas", Hugo Grotius, Samuel Pufendorf, Jean Barbeyrac e Jean-Jacques Burlamaqui. Para os Enciclopedistas, estes autores eram as principais autoridades em matéria de moral e de política; Denis Diderot, organizador do empreendimento editorial mais significativo do século XVIII, responde vigorosamente no artigo da Enciclopédia, intitulado Direito Natural, aos ataques de Rousseau. Rousseau, por sua vez, defende e desenvolve os pontos principais de sua crítica num capítulo introdutório do $\mathrm{Ma}$ nuscrito de Genebra, uma primeira versão do Contrato Social, que permaneceu inacabada. Podemos, porém, considerar Samuel Pufendorf, jurista e professor alemão, o autor representativo da doutrina da lei natural atacada por Rousseau. ${ }^{4}$ Pufendorf opera um compromisso explícito entre Hobbes e a lei natural tradicional. De Hobbes, retém a doutrina individualista do contrato social quanto ao direito de governar, mas rejeita categoricamente sua doutrina da soberania em proveito de um código laico da lei natural que expõe detalhadamente em seus livros. Segundo o jurisconsulto, na origem os homens viviam num estado de natureza onde eram livres, iguais e sem governo. Por conseguinte, qualquer governo advém de um contrato social, como ensinou Hobbes. Embora os homens sejam naturalmente apolíticos, eles são por natureza parcialmente egoístas, são, com efeito, plenamente sociais e sociáveis. Desde então, o estado natural era um estado social e pacífico, onde podiam aplicar e aplicavam a lei natural tal como a descobriu a razão. Todavia, o fizeram de modo tão imperfeito que os Estados e os governos acabaram por ser instaurado, precisamente para aplicar e seguir a lei natural e não para criar a própria lei livremente, em virtude de uma soberania absoluta. ${ }^{5}$ Assim a justiça e as regras do justo e do injusto emanam da natureza, enquanto o Estado e a autoridade política são artificiais, saídas de um consentimento.

Contra Pufendorf, Rousseau defende que a justiça não é natural. Ele recusa todo compromisso com a lei natural tradicional para voltar à posição de Hobbes. Em suas linhas gerais, o argumento de Rousseau comporta duas partes, qual seja, para que uma lei natural coercitiva exista, duas coisas são requeridas: a lei deve ser conhecida dos homens ou corretamente

4 Samuel Pufendorf, além de jurista e professor, foi historiador e teórico da lei natural. Segundo Robert Derathé, de todos os autores pertencentes à escola do direito natural moderno, foi Pufendorf que recebeu de Rousseau a maior consideração (cf. Derathé, 1970, p.83-4).

5 Pufendorf desenvolve a partir da idéia de direito natural a teoria voluntarista do contrato - a passagem para o Estado é uma aliança (foedus) e não um contrato privado, nem a decisão de um só indivíduo. No seu entender, o poder político tem uma origem racional: nasce do encontro de vontades individuais para dar o consentimento a um magistrado, através de um acordo. Toma-se, então, consciência de três idéias que vai influenciar o pensamento político moderno: primeira, o Estado não tem legitimidade para contrariar os direitos naturais; segunda, o direito natural deve ser fonte do direito positivo ou construído; terceira, o homem tem uma dignidade inalienável, na medida em que, pela própria natureza, é sujeito de direitos. Segundo tal ponto de vista, o direito natural está, no estado de natureza, limitado ao indivíduo e pode ser reconhecido através de três fontes: a iluminação divina, a luz da razão e a voz da consciência. É válido para todos os homens, em todos os tempos e lugares, independentemente de ideologias ou crenças. 
"dispensada", e ela deve ser aplicada ou ser o objeto de uma sanção. Ora, no estado originário de natureza, os princípios racionais da lei natural que expõe Pufendorf não podem ser conhecidos, e, por conseguinte, quando puderem ser conhecidos, não serão aplicados por natureza.

Como a crítica de Rousseau se encontra dispersa por vários escritos e por vários contextos, interessa, antes de mais, isolar um dos seus aspectos, de modo a elegê-lo como fio condutor capaz de orientar a análise que aqui pretendemos. É com este fim que será evocada a tese rousseauneana segundo a qual os limites da teoria da lei natural, ou seja, os limites da teoria no qual repousa o conceito político de poder soberano, desemboca necessariamente na emergência de uma desnaturalização do próprio político (cf. Bachofen, 2002, p.40-5; Lenoir, 2003, p.314-5).

\section{Pufendorf e a teoria da lei natural}

No processo de contestação da teoria hobbesiana do estado de natureza como estado de guerra generalizado, ${ }^{6}$ Pufendorf distingue e assinala o lu-

6 Não há, aqui, consenso entre os estudiosos de Pufendorf. Alguns comentadores importantes ressaltam a influência desempenhada pela antropologia negativa de Hobbes na teoria de Pufendorf. A razão principal a favor da recepção hobbesiana pode ser descrita desta forma: "no estado de natureza, os indivíduos estão originariamente centrados sobre a singularidade, e não relacionados com outra coisa. Se eles entram em alguma forma de sociedade, isso não se deve a um impulso natural irresistível nem à busca da virtude, mas a um cálculo que visa à utilidade individual. Na medida em que a sociabilidade do homem é finalizada à conservação de si, ele é, paradoxalmente, profundamente egoísta. A mesma definição da lei de natureza, lugar fundamentalmente de todo o direito natural, mostra explicitamente que a necessidade de sociedade é uma conseqüência da necessidade de conservação e que, portanto, o verdadeiro princípio do direito natural é a autoconservação do individuo" (Scattola, 2005, p.104). Duas teses importantes podem ser retiradas do comentário de Scattola: a primeira, Pufendorf atribui à sociabilidade humana uma função central (primeira lei de natureza), mas ressalta que o seu papel não implica absolutamente que os homens sejam sociais e o corpo político seja "co-essencial" ao homem e não possam existir indivíduos fora da sociedade. Para Scattola, "o princípio de sociabilidade tem, com efeito, um valor exclusivamente epistemológico: é o fundamento lógico que permite a dedução do conjunto jusnaturalista" (Scattola, 2005, p.105). A segunda tese, porém, sugere a presença de um traço paradoxal na doutrina de Pufendorf, qual seja, "a sociedade humana nasce da sociabilidade natural do homem, mas é fundada recorrendo a um segundo princípio, a imbecillitas, ou seja, a insegurança do direito e, em última instância, o interesse individual" (Scattola, 2005, p.105). Sem explorar plenamente aqui as teses de Scattola, aliás retomada de Brufau Prats (1968) e Fiametta Palladini (1990), e suas influências hobbesianas, que por si só são controversas, limito apenas em descrevê-las e sugerir uma pouco de prudência na recepção da tese de Pufendorf discípulo de Hobbes, pois não faltam elementos teóricos sugerindo uma natureza humana boa e pacífica e comentadores dispostos a sustentá-la. Em geral, os defensores dessa tese defendem o seguinte: o jusnaturalismo moderno é unânime no combate da idéia de um direito de natureza que seria potência ou força. Simone Goyard-Fabre escreve: "Pufendorf, contra Hobbes, se junta a Grotius para ver no direito natural não uma potência física quantificável, mas uma qualidade moral que se avalia no homem em vista de sua natureza racional" (Goyard-Fabre, 2002, p.58). Todescan, aliás, lembra que falta a imbecillitas a agressividade característica da tese hobbesiana, pois a fragilidade humana por si só não estimula a bestialidade do indivíduo no estado de natureza, um terceiro elemento vem justamente preencher este requisito, a pravitas animi, que incita o homem a prejudicar o seu semelhante (Todescan, 2001, p.28). 
gar próprio do direito natural no pensamento filosófico e jurídico do século XVII. Partido da filosofia política e dos princípios racionais axiomáticos, evidentes, deduzidos com coerência (more geometrico), o autor saxão tenta fornecer uma solução definitiva para o problema da justiça e responder à questão sobre o que é certo e errado nas relações mútuas dos homens. Define o fundamento da teoria jusnaturalista ao defender a tese segundo a qual, independente das leis civis e anterior à sua convenção humana, existem ordem moral e regra de justiça universais (as leis de natureza), ${ }^{7}$ que indicam ao homem os seus deveres e o proíbem de fazer o mal. O homem tem a capacidade e o dever de criar as condições propícias para um bom relacionamento com os outros indivíduos da mesma espécie. As leis que comandam as ações mútuas dos homens estão arraigadas na sua natureza racional e são imutáveis e eternas: quem não as respeita ofende a sua própria dignidade de homem. Desse modo, o modo de ser do homem é viver em sociedade pacificamente: "Com estas premissas parece que a lei natural fundamental é a seguinte: cada homem deve cultivar e manter na medida do possível a sociabilidade" (Pufendorf, 1998a, II, III, §15). ${ }^{8}$

As doutrinas do direito natural moderno estavam de acordo num ponto: na existência de um ideal de justiça anterior ao Estado e independente da vontade arbitrária dos homens. Como nos períodos antigo e medieval, um problema se põe aos juristas e filósofos dos séculos XVII e XVIII: a justiça é uma convenção ou uma lei absoluta? Ela é uma invenção dos homens, ou uma ordem da razão eterna? Existe em si? Ou é apenas uma relação arbitrária e variável, mudando com o tempo e os lugares? Há um direito e, por conseguinte, há direitos? Ou o único direito possível é o direito do mais forte? O problema é fundamental, trata-se de saber se o direito é uma criação do Estado (ou da sociedade), se ele é fruto do trabalho perspicaz do legislador ou se, ao contrário, existe regras de justiça absolutas, imutáveis, universais que se impõem aos governantes, dominam o Estado e inspiram o direito positivo. Há no fundo da alma humana uma necessidade incoercível de justiça? A razão não indica certas regras imutáveis, princípios essenciais que devem inspirar o legislador?

7 Reportando à lei da natureza, Hobbes escreve: "Os príncipes sucedem uns aos outros, e um juiz passa e outro vem; mais, o céu e a terra passarão, mas nem um artigo da lei da natureza passará, porque ela é a eterna lei de Deus" (Hobbes, 1996, p.110).

8 Pufendorf empreende uma retomada do princípio fundamental do direito de natureza segundo o método da ciência natural, o método analítico (cf. Welzel, 1993, p.73). Ao aplicar este método, porém, o autor decompõe a natureza humana em três elementos básicos para determinar a lei de seu ser. Estes componentes fundamentais sintetizados na socialitas (sociabilidade) são: o amor sui, o amor de si ou o impulso de autoconservação; a imbecillitas e a naturalis indigentia; e a pravitas animi, que incita o homem a prejudicar o seu semelhante. 
Atribui-se ao direito natural moderno o caráter de ser filosófico pois os seus teóricos acreditavam na razão para deduzir o direito da natureza das coisas. Eles acreditavam poder determinar um sistema completo, um código de regras universais envolvendo o conjunto das instituições e das atividades do homem. À exceção de Pufendorf, imediatamente admoestado por Leibniz, e de Christian Thomasius, todos os representantes do jusnaturalismo moderno ainda confundem direito e moral. ${ }^{9} \mathrm{O}$ direito natural se estende indistintamente às ações internas e externas do homem, envolve o conjunto de seus deveres. Ora, os preceitos concernentes ao amor, amor de Deus, amor do próximo e amor de si, advêm da moral e não da justiça.

A existência de um direito natural uma vez admitida, portanto, duas questões fundamentais se colocam ao filósofo do direito: como conhecer a justiça objetiva? Qual será o fundamento da obrigação de fazer ou não fazer o que manda o direito natural? Em seus contornos mais gerais, os sistemas defendem a possibilidade do direito natural ser conhecido somente pelas luzes da razão, embora sejam reforçados pela revelação. Há entre os principais representantes jusnaturalistas modernos divergências consideráveis quanto à segunda questão: Hobbes faz repousar o direito sobre o poder irresistível, Grotius sobre a natureza das coisas, Pufendorf sobre a vontade de um superior ao mesmo tempo forte e justo (e não sobre a vontade arbitrária de um superior, como pretendia Leibniz), Leibniz sobre a razão de Deus e a natureza das coisas. Tal é o estado da questão, no momento em que Pufendorf publica o seu De jure naturae et gentium. Vejamos como o autor alemão resolveu tal problemática.

No capítulo do De Jure Naturae et Gentium dedicado às leis naturais, Pufendorf explica que o homem, refletindo sobre a sua natureza e constituição física, descobre imediatamente e de modo claro e evidente a necessidade de por um freio à ilimitada liberdade de que possui no estado de natureza. A liberdade aqui se revela ao mesmo tempo inútil e danosa. Para cumprir tal finalidade, porém, ele precisa recorrer à razão, a qual impõe as leis naturais, formulando assim a regra básica do agir humano. ${ }^{10}$ As leis na-

9 A compreensão desta separação não elimina uma relação estreita entre ambos. Como escreve Michel Villey: "em filosofia do direito, tudo é solidário, e moral e direito são tão vizinhos que nada do que acontece com um deixa de repercutir no outro" (Villey, 2005, p.340). Sobre o autor cuja cultura resume a do século XVI ao mesmo tempo em que transmite seu legado aos juristas do futuro, e o fenômeno da absorção do direito na moralidade, Villey escreve: "Jus gentium, regras apoiadas no consentimento universal ou certificadas pela autoridade dos juristas romanos, e até regras do 'direito voluntário', contrato social estabelecendo o regime dos Estados modernos, pactos e tratados vão de fato fornecer a substância ao sistema de Grotius. Mas todo o esforço de sua doutrina consiste em reduzir convencionalmente essas regras à fonte primeira, a razão, ou seja, a lei moral" (Villey, 2005, p.654).

10 A razão natural é fundada, portanto, sobre a natureza humana e é definida como consciência moral. Pufendorf compartilha com seu mestre Erhard Weigel a doutrina dos entia moralia, de idéias 
turais fundamentais que orientam o homem no estado de natureza - que permitem deduzir todas as normas práticas - nos impõem: primeiro, o respeito à pessoa do outro ("ninguém deve ofender os outros salvo se é provocado"); segundo, o respeito à propriedade de outrem ("a cada um deve ser permitido usufruir seus próprios bens"); terceiro, o respeito aos pactos ("cada um deve manter a promessa empenhada"); e quarto, o respeito aos interesses alheios ("cada um deve promover com ânimo feliz a vantagem de outrem nos limites do possível e segundo as obrigações mais rigorosas que nos atribuímos") (Pufendorf, 1998a, II, II, §9). A fundação racional das leis naturais não comporta, todavia, uma solução inata, aliás, duramente criticada por Pufendorf: as leis naturais não são, portanto, impressas na mente do homem no instante de seu nascimento, mas, ao contrário, é o produto de uma reflexão madura e dependem de um processo árduo de aprendizagem (cf. Pufendorf, 1998a, II, III, §13).

Tais elaborações racionais não esgotam, porém, o pensamento de Pufendorf. Examinando na sua complexidade o tema do direito natural, ele se põe numa posição intermediária que busca superar a rígida alternativa entre uma aproximação em termos estritamente racionalistas, por um lado, e em termos voluntaristas, por outro (cf. Pufendorf, 1998a, II, III, §§4-5). Na página em que enfrenta a questão do fundamento do direito natural, e após a avaliação do bem e do mal nas ações humanas, Pufendorf propõe como objetivo conciliar as duas tradições teológicas do racionalismo e do voluntarismo que consideravam, no primeiro caso, o bem e o mal como qualidades inerentes às ações idênticas (e por esse motivo, portanto, comandada ou proibida por Deus) e, no segundo caso, como qualidades atribuídas às ações segundo a sua conformidade ou não à norma divina (boas quando obrigadas e nocivas quando proibidas). Segundo Pufendorf, as duas doutrinas extremas que colocam o fundamento do "ius naturae" só na razão ou na vontade divina são ambas parciais e refutáveis. Para ele, portanto, a lei natural repousa tanto sobre a onipotente vontade de Deus (que desejou que o homem fosse criado) como sobre a infinita sabedoria ou razão de Deus, desejando que as leis naturais fossem conformes à natureza do homem.

Pufendorf volta por isso ao argumento já enfrentado a propósito dos entes morais para confirmar o seguinte: para estabelecer o que é justo ou injusto o homem não pode basear-se somente sobre a razão, mas deve fazer também referência a um código de normas, aquele da lei moral. Não é pos-

práticas da consciência, que são um dote natural de cada consciência humana, enquanto ela é prática. Pufendorf, por isso, está convencido de que a consciência humana contém um conhecimento pleno dos deveres e direitos dos homens. São três os deveres: deveres para com Deus, para com o próximo e para consigo mesmo (cf. Pufendorf, 1927, I, IV; I, V, §6; I, VII. Sobre a relação de Pufendorf com seu mestre Weigel, cf. Behme, 1995, p.34-6). 
sível, com efeito, conceber abstratamente a bondade ou a maldade de um ato anterior a qualquer lei e aquém da imposição de um superior - neste caso específico, Deus, criador das leis de natureza - que vincula a obediência. Em outras palavras, atento às dificuldades de que é herdeira a noção de obrigação, Pufendorf sublinha que seu estudo deve ser circunstanciado. No capítulo dos Elementa Jurisprudentiae Universalis que consagra a esta noção (cf. Pufendorf, 1999, I, XII), reconhece que ela pode ser definida, conforme a tradição romana, como o vinculum iuris que une stricto sensu devedor e credor. Contudo, aprofundando o seu sentido, segundo uma filiação à escolástica (cf. Goyard-Fabre, 1994, p.29-39), a obrigação é caracterizada pelo vínculo que une o inferior ao superior: assim, na família, a esposa é obrigada em relação ao marido, as crianças em relação aos parentes próximos, os servidores em relação ao senhor. Nas sociedades civis, porém, o cidadão tem a obrigação de obedecer ao soberano, e a obrigação mais forte na grande comunidade humana é aquela de Deus dirigida diretamente à inteligência dos homens. Sobre a origem das obrigações, utilizando ainda o texto dos Elementa, pode-se sustentar que elas procedem tanto das leis civis como das leis naturais, pois as leis civis devendo respeitar as leis naturais fundamentais, as obrigações derivam, por patamares sucessivos, da lei natural instituída por Deus (cf. Pufendorf, 1999, I, XII, §14). ${ }^{11}$ Desse modo, Pufendorf pode afirmar, no De jure naturae et gentium, que a obrigação "é uma qualidade moral operadora" que permite fazer ou sofrer alguma coisa. Não estabelecendo nenhuma distinção entre a moral e o direito, Pufendorf acrescenta: "Para ser susceptível de obrigação, é preciso, de um lado, advir de um Superior, e de outro, ter um entendimento que permita conhecer a regra prescrita e uma vontade livre como princípio interior sempre pronto para voltar-se para qualquer lado, mas consciente de que quando o Superior prescrever alguma regra, estar convencido que não deve dela se desviar" (Pufendorf, 1998a, I, VI, §8). Isto significa que Pufendorf atribui à obrigação um sentido ético e existencial mais profundo e verdadeiro do que foi definido por Justiniano na noção de vinculum iuris. O remorso, pergunta o jurisconsulto alemão, não tortura a consciência dos que desejam escapar à obrigação? E, sobretudo, o elemento voluntarista inerente à obrigação a distingue invariavelmente do constrangimento: enquanto este último "nos leva a fazer alguma coisa (...) unicamente por causa de uma força maior que vem de fora", a obrigação "nos determina a agir por um princípio de cons-

11 No De Jure, Pufendorf retoma o tema e escreve: "É preciso tomar por princípio necessário que a obrigação da lei natural vem de Deus, pois, na qualidade de criador e de condutor soberano do gênero humano, prescreve aos homens com a autoridade a observação desta lei" (Pufendorf, 1998a, II, III, §19). 
ciência, e pela persuasão recebida da justiça, conforme os deveres que nos impõem" (Pufendorf, 1998a, III, IV, §6).

O saxão, porém, põe-se em guarda e exige cautela também em relação ao perigo de se cair no erro oposto e identificar a lei de natureza ao absoluto e insondável mandamento divino. Livre para criar, Deus é de algum modo vinculado à sua criação, por isso uma vez constituído o homem como ser racional e sociável, impõe-se necessariamente uma ordem de valores subseqüentes. A imposição dessa ordem, porém, apresenta-se como uma necessidade relativa sem qualquer relação como uma metafísica realista, mas simplesmente uma ordem que faz ressaltar a racionalidade do voluntarismo de Pufendorf. Além disso, é preciso considerar, contra a posição extremada dos voluntaristas, o autor afirma a imutabilidade da lei natural, diminuindo assim a condição absoluta da onipotência divina que alguns se preocupavam em salvaguardar até as últimas conseqüências.

$\mathrm{Na}$ tentativa de conciliar duas tradições opostas, Pufendorf acaba, no entanto, por oscilar entre posições nem sempre homogêneas: as leis naturais são as leis que o homem conhece mediante a razão e o fundamento do direito natural das coisas que nos dá a certeza da sua imutabilidade e universalidade. Todavia, tais leis não prescrevem ou condenam ações intrinsecamente boas ou más, mas apenas orientam a razão sobre o desejo de Deus que obriga os homens a elas obedecerem; o fundamento do direito natural está, portanto, também na vontade divina. Em suma, Pufendorf aparece como um voluntarista que reconhece a autoridade da razão e, ao mesmo tempo, um racionalista que sabe atribuir o justo peso aos dados da experiência. A razão permaneceria abstrata se não pudesse apoiar-se sobre a natureza da coisa que formou a experiência do homem; mas a natureza da coisa remete, por sua vez, à vontade divina que a criou deste modo e não de outro.

O homem, então, no curso da sua vida compara-se com toda uma série de deveres, que servem para regulamentar o seu comportamento e estão reunidas em duas grandes classes: os deveres absolutos (não fazer o mal, respeitar a palavra empenhada, reparar os danos provocados, etc.) que, pertencentes aos homens enquanto tais são universais e eternos e se erguem sobre o vínculo da consciência, e os deveres convencionais que derivam, ao contrário, dos acordos estipulados, em virtude dos quais cada dever subscrito corresponde para o outro o direito de exigir o seu cumprimento. Os deveres absolutos são obrigações naturais, os deveres convencionados são obrigações civis ou jurídicas (cf. Pufendorf, 1998a, III, IV, §1).

Desse modo, as obrigações naturais vinculam cada um individualmente e segundo a consciência, são realmente obrigações morais, e as obrigações convencionais, que são as obrigações da sociedade civil e da lei positiva, vinculam os homens associados e "in foro externo". Aos deveres absolutos que obrigam interiormente correspondem direitos do mesmo ti- 
po, assim como aos deveres convencionais impostos pelo Estado correspondem direitos que malogrados, desrespeitados, pode-se recorrer à força pública, aos direitos perfeitos. ${ }^{12}$ Deste ponto de vista, portanto, o estado de natureza é apresentado como o estado dos direitos imperfeitos, pois não são susceptíveis de coação externa. Sobre a base de uma análise da obrigação natural, Pufendorf chega mesmo a distinguir entre direitos imperfeitos e direitos perfeitos e a colocar um novo critério de demarcação, a saber: enquanto a moral tem por fundamento a natureza racional do homem, o direito positivo tem sua origem na vontade e nas convenções humanas e está vinculado ao âmbito do comportamento externo e das relações interpessoais.

\section{Os limites da lei natural: a crítica de Rousseau}

É esta tradição que Rousseau combate. A justiça, como já foi dito, não é para o genebrino natural. Ele divide em duas partes a sua objeção. A primeira parte do argumento emana diretamente da premissa rousseauneana da falta de sociabilidade do homem: porque a razão não pode ser desenvolvida sem a sociedade e a linguagem, o homem natural e solitário não podia conhecer absolutamente nenhuma lei racional da natureza, nem ser submetido à nenhuma lei deste gênero. Se Rousseau afirma que não há lei natural no estado de natureza, isto é, código moral obrigatório no qual os homens poderiam e deveriam conscientemente se submeter, ele sustenta, porém, que há um direito natural, qual seja, um modo natural de se relacionar uns com os outros, mediante o qual os homens se conformam cega e instintivamente. Nesse sentido, de suas inclinações fundamentais à sua própria conservação e à piedade, os homens naturais obedeciam, sem saber, ao que Rousseau chama a "máxima da bondade natural" ("Fais ton bien avec le moindre mal d'autrui qu'il est possible"). Mas o desenvolvimento da razão, aumentando as paixões e enfraquecendo a piedade, destrói o direito natural. Além disso, mesmo que concedêssemos a Pufendorf que o homem era sociável e plenamente racional no estado de natureza a dificuldade permaneceria. Para Rousseau, "os modernos só reconhecem como lei uma regra prescrita a um ser moral, isto é, inteligente, livre e considerado nas suas relações com os demais seres, limitando conseqüentemente ao único animal dotado de razão, isto é, ao homem, a competência da lei natural; definindo, porém, esta lei cada um a seu modo, estabelecem tudo sobre princípios tão metafísicos que há, mesmo entre nós, muito poucas pessoas em situação de compreender esses princípios, em lugar de poderem encontrá-los por si

12 Para a distinção entre direitos perfeitos e direitos imperfeitos, cf. Pufendorf, 1998a, I, VII, §7. 
mesmos. De forma que todas as definições desses homens sábios, aliás em perpétua contradição entre si, concordam unicamente quanto a ser impossível compreender a lei da natureza e, conseqüentemente, obedecê-la, sem ser grande pensador e profundo metafísico. Tal coisa significa, precisamente, que os homens tiveram de utilizar, para o estabelecimento da sociedade, luzes que só se desenvolvem com muito trabalho e para poucas pessoas, no próprio seio da sociedade" (Rousseau, 1964, p.125).

Estas observações, fundadas sobre um raciocínio abstrato, são confirmadas pelos fatos históricos: "A este propósito, os fatos confirmam perfeitamente o que a reflexão nos ensina, e só ao voltar-nos para os tempos veremos facilmente que as idéias saudáveis do direito natural e da irmandade de todos os homens foram disseminadas bem tarde, e fizeram no mundo um progresso tão lento que só o Cristianismo conseguiu generalizá-las suficientemente" (Rousseau, 1964, p.287). Assim, conclui o autor, a primeira condição da lei natural, qual seja, que ela seja dispensada e conhecida por natureza, não é preenchida.

Mas mesmo se estas pretensas leis de justiça natural fossem conhecidas, acrescenta Rousseau na segunda parte de seu argumento, elas não seriam moralmente nem obrigatórias nem válidas, pois não são aplicadas por natureza. Para apreciar o justo valor desse argumento sobre as sanções susceptíveis de sustentar a moralidade, importa não "kantianizar" a tradição da lei natural, que é essencialmente heterônoma. Rousseau e seus adversários estão de acordo sobre o fato de que para serem válidas e obrigatórias, as exigências da lei natural devem estar enraizadas nas inclinações e no cumprimento mesmo da natureza humana (cf. Rousseau, 1964, p.123-4). Como diz Jean-Jacques Burlamaqui, a lei natural é o conjunto das "regras que só a razão prescreve aos homens, para conduzi-los seguramente ao fim que devem se propor, e que se propõem todos realmente, quero dizer, à verdadeira e sólida felicidade" (Burlamaqui, 1984, I, I, §1; cf. Gagnebin, 1944, p.95-101).

Para que uma regra de justiça seja válida ou obrigatória, ela deve promover o bem natural de todos enquanto todos a obedecem. Mas, além disso, ela deve ter uma força ou ser susceptível de uma sanção saída do poder da razão, de uma paixão benevolente ou de um agente exterior, quer seja ele natural ou divino. Esta sanção deve poder garantir a cada um que os outros se conformarão efetivamente à regra, ou, ao menos, ela deve poder indenizar cada um pela desobediência dos outros. "Esta justiça, para ser admitida entre nós, escreve Rousseau, deve ser recíproca" (Rousseau, 1964, p.378). Desde então, se a lei natural não é nem aplicada nem observada por todos, e se ela é ao mesmo tempo prejudicial àqueles que a obedecem, ela não pode ser naturalmente obrigatória ou válida. Em outros termos, a questão da validade de um modelo moral não pode ser inteiramente distinguida da questão de seus efeitos no mundo. 
Ora, Rousseau afirma que nas etapas ulteriores do estado de natureza a razão é efetivamente desenvolvida, desenvolvimento concomitante com o aumento dos desejos e a constituição da sociedade não política. Teoricamente, porém, os homens estão na posição de elaborar uma concepção racional da justiça ou do bem comum. Todavia, constatamos "que o progresso da sociedade abafa a humanidade nos corações, despertando o interesse pessoal, e que as noções da lei natural (...) não começam a se desenvolver senão quando o desenvolvimento anterior das paixões torna impotentes todos os seus preceitos" (Rousseau, 1964, p.284). Uma vez alcançado o pleno desenvolvimento da razão, o estado de natureza de Rousseau torna-se essencialmente o mesmo de Hobbes, um "estado de guerra absolutamente horrível"; e neste ponto, a sua objeção à lei natural é igualmente a mesma do pensador inglês. Rousseau imagina o homem no estado de natureza assim descrito: "Com a voz abafada pelo sábio, o indivíduo independente diz: "Tenho consciência de que trago horror e confusão à espécie humana, mas é preciso que eu seja infeliz se evito fazer com que os outros o sejam, e ninguém me é mais caro do que eu próprio. Em vão tentaria conciliar o meu interesse com o dos outros. Tudo o que ouço sobre as vantagens da lei social estaria bem se, quando a observassem escrupulosamente com respeito aos outros, tivesse a certeza de que todos a observariam com relação à minha pessoa. Mas, que garantia disso posso ter? E haveria pior situação para mim do que me expor a todos os males que os indivíduos mais fortes poderiam fazer-me sem ousar compensar-me com relação aos mais fracos? Se não tenho uma garantia contra todas as ações injustas, não se pode esperar que deixe de praticá-las também. Em vão me dizem que ao renunciar aos deveres imposto pela lei natural desprezo ao mesmo tempo os seus direitos; que a minha violência justificará todas as violências que os outros poderiam praticar contra mim. Estou propenso a concordar, mas não posso entender de que forma a minha moderação poderia proteger-me. Além disso, deverei fazer com que os fortes se aliem a mim, compartilhando com eles os despojos dos fracos, o que seria melhor do que a justiça, tanto em termos de vantagem como de segurança'" (Rousseau, 1964, p.284-5). ${ }^{13}$

13 A título de comparação, Pufendorf escreve: "Assim, o homem é um animal desejoso de conservarse, por si só necessitado, incapaz de sobreviver sem a ajuda dos seus semelhantes, idôneo a promover vantagens recíprocas; e, ao mesmo tempo, o homem é malvado, malicioso, suscetível, inclinado e capaz de infringir prejuízos aos outros. Por isso, para salvar-se ele deve necessariamente ser social" (Pufendorf, 1998a, I, III, §7). Em outra passagem que parece confirmar, em parte, as teses de Brufau Prats e Palladini, o jurisconsulto conclui: "Não é suficiente, portanto, dizer que o homem é levado pela própria natureza a entrar em sociedade e que ele não pode nem quer ficar de fora dela. Pois, com efeito, o homem é, com toda a evidência, um animal que ama a si mesmo e ao seu proveito sobre todas as outras coisas: mesmo que ele busque espontaneamente a sociedade, deve ter certeza de auferir alguma vantagem" (Pufendorf, 1998a, II, V, §2) 
É naturalmente prejudicial conformar-se às regras de "justiça", pois são regras desprovidas de toda sanção natural. Por conseguinte, estas regras não são nem obrigatórias nem válidas.

Em última instância, Rousseau rejeita o compromisso da lei natural adotado por Pufendorf, Diderot e outros autores. Segundo este compromisso, a justiça é natural e o Estado é artificial. Rousseau mostra que a pretensa lei natural conhecida e observada no estado de natureza "é uma verdadeira quimera; pois as condições são sempre desconhecidas ou impraticáveis, e que é preciso necessariamente ignorá-las ou infringi-las" (Rousseau, 1964, p.284). Nesse sentido, a crítica de Rousseau realmente alcança, de maneira bastante mordaz, a literatura contratualista moderna. Não se pode deduzir algo de nada. O papel dos projetos abstratos é muito menor, e o dos projetos empíricos controversos muito maior, do que os teóricos desse campo estão dispostos a admitir. Nunca houve um contrato social, e aqueles que recorrem a uma idéia de homem natural ou pré-político como criador das instituições políticas expressam, invariavelmente, uma versão da falácia que Rousseau atribuía a Hobbes: a de reificar aspectos do comportamento e das instituições aceitos de sua época, atribuindo-os ao homem "natural". ${ }^{14}$

\section{Conclusão}

Algumas considerações finais são necessárias. Na verdade, duas considerações distintas sobre a questão da existência da lei natural e o seu papel na formação do direito. A primeira, sugere uma separação entre os dois representantes mais significativos do direito natural moderno, Hugo Grotius e Samuel Pufendorf, se Simone Goyard-Fabre tem razão quando propõe uma separação entre a via racional e a via voluntarista do direito natural moderno, que impõe uma heterogeneidade complexa às teorias jusnaturalistas do século XVII. Por um lado, o racionalismo de Grotius, por outro, o voluntarismo de Pufendorf (Goyard-Fabre, 1996, p.171). A segunda, apresenta alguns pontos importantes do projeto de Rousseau, sem, contudo, esgotá-los, mas visando ressaltar a crítica do perigoso empreendimento de naturalização do político levado a cabo pelos contemporâneos do autor.

14 Embora o argumento de Rousseau seja simples e altamente plausível, há alguns problemas quanto a pertinência da acusação. Apesar das considerações do autor, as doutrinas tradicionais da lei natural não repousam explicitamente sobre a tese do conhecimento e observação da lei natural no estado pré-político. Como interpretar, assim, a afirmação de Pufendorf sobre a validade da tese e sua rejeição defendida por Rousseau? Tema difícil, de fato, e que para alguns sugere uma antecipação de Pufendorf às objeções rousseaunianas. 
Enquanto Grotius sustenta que a lei natural é imanente à razão humana, Pufendorf defende um retorno à natureza objetiva das coisas que a razão tem apenas por tarefa discernir. Ele reprova o círculo vicioso da argumentação grotiana ao estabelecer na própria "razão a regras das máximas da Razão" (Pufendorf, 1998a, II, III, §23). Embora o autor saxão não negue o papel da lei natural como regra de orientação de cada um na qualidade de "animal racional" (Pufendorf, 1998a, II, III, §1), afirma porém que "a razão não é, propriamente falando, a Lei natural, mas unicamente um meio de conhecê-la, se a colocamos em uso como é preciso" (Pufendorf, 1998a, II, III, §20). Assim, conclui Pufendorf, "quando sustentamos que a lei natural é fundada sobre as máximas da reta razão, queremos dizer com isso que o entendimento humano tem a faculdade de descobrir clara e distintamente, ao refletir sobre a natureza e a constituição dos homens, a necessidade de se conformar a sua conduta às leis naturais" (Pufendorf, 1998a, II, III, §20). As leis naturais são as leis que a razão descobre no estudo da constituição íntima da natureza humana. Ora, qual é esta constituição? Para Pufendorf, ela não é outra coisa que a própria manifestação do caráter tipicamente social dos homens. Nas palavras do autor: "Eis a lei fundamental do direito natural: cada um deve ser levado a formar e entreter, enquanto depende dele, uma sociedade pacífica com os outros, conforme a constituição e o fim do gênero humano sem exceção" (Pufendorf, 1998a, II, III, §15). Tudo o que contribui para ampliar a sociabilidade universal entre os homens deve ser reputado como prescrito pelo direito natural. Desse modo, o sistema ou a teoria da sociabilidade, fundamento da construção teórica de Pufendorf, exige um desenvolvimento e justificação posterior. O autor explica os meios mais eficazes para suprimir as más ações, as tendências desviantes e egoístas, os maus usos e costumes, e tudo o que pode prejudicar ao outro e à sociedade. Estes meios, aliás, já estão presentes e reconhecidos no estado de natureza, e se efetivam quando os homens decidem construir a cidade, o Estado, isto é, quando decidem viver e realizar a sociabilidade. Em outras palavras, Pufendorf inicia com grande esforço uma abordagem teórica objetivando justificar a existência das sociedades e a inclusão do homem nelas. Pufendorf desenvolve a partir da idéia de direito natural a teoria voluntarista do contrato.

Desde as primeiras linhas do Prefácio ao Discurso sobre a desigualdade, Rousseau defende a necessidade de uma transformação radical do método de investigação nas questões humanas e sociais. Para estudar uma questão particular como a proposta pela Academia de Dijon, portanto, é preciso resolver previamente a questão do homem, "o conhecimento mais útil e menos desenvolvido". Nesse sentido, deve-se descobrir a sua "constituição original" segundo a metáfora da "estátua de Glaucus", tão deteriorada pela ação do tempo, que se tornou irreconhecível. Do mesmo modo, as vicissitudes histórico-sociais deformaram o homem até convertê-lo num 
"contraste deformado da paixão que acredita raciocinar e do entendimento que delira" (Rousseau, 1964, p.122).

Não deixa de ser significativo que Rousseau, no Segundo Discurso, prefira falar de "constituição humana" em vez de "natureza humana". A razão disso, a meu ver, é que, partindo da hipótese para ele incontestável segundo a qual mudanças significativas no ser originário do homem foram produzidas durante a sua existência temporal, as transformações vivenciadas são de ordem sócio-cultural e não fisiológica. Como é possível diferenciar, então, o que há de originário e de artificial na "natureza atual do homem"? Como reconstruir "um estado que não mais existe, que talvez nunca tenha existido, que provavelmente jamais existirá, e sobre o qual se tem, contudo, a necessidade de alcançar noções exatas para bem julgar de nosso estado presente"? É uma investigação digna dos maiores filósofos, dos "Aristóteles e Plínios de nosso século". A questão poderia assim ser formulada: "que experiências seriam necessárias para se chegar a conhecer o homem natural?; e quais são os meios para se fazer tais experiências no seio da sociedade"? (Rousseau, 1964, p.123-4).

Na realidade, a reconstrução experimental das origens foi um projeto defendido por vários autores do século XVIII. Basta lembrar o projeto de Buffon (cf. Reale, 1983, p.52-70). Rousseau, porém, o considera irrealizável como tal. Não obstante, sem o conhecimento "dos fundamentos reais da sociedade humana" não é possível formular "uma verdadeira definição do direito natural", que faça menção necessariamente à "natureza humana"; portanto, é preciso conhecer previamente "a natureza do homem, sua constituição e seu estado" para "deduzir os princípios daquela ciência". Assim sendo, tanto os filósofos antigos como os modernos apresentaram noções tão "metafísicas" que é impossível conhecer a lei natural se não se é "um grande raciocinador e um profundo metafísico". O mais grave, porém, não é o seu caráter abstrato, mas a impressão de que a teoria jusnaturalista supõe que os homens conhecem regras tão complexas como as da "utilidade comum". Por definição, a lei natural deve ser muito simples e imediatamente conhecível, mais ainda, deve apoiar-se sobre "dois princípios anteriores à razão", os princípios de autoconservação (amor de si) e de "compaixão" (pitié). Só combinando estes dois princípios, "sem necessidade de apelar ao de sociabilidade", poderemos formular "todas as regras do direito natural", regras que "a razão, depois, é forçada a restabelecer com outros fundamentos quando, por seus desenvolvimentos sucessivos, chega a ponto de sufocar a natureza" (Rousseau, 1964, p.125-6). 
SAHD, Luiz Felipe Netto de Andrade e Silva. Natural law theories: Pufendorf and Rousseau. Trans/Form/Ação, (São Paulo), v.30(2), 2007, p.219-234.

- ABSTRACT: The present article aims at reconstructing Jean-Jacques Rousseau's central arguments. Against Samuel Pufendorf, Rousseau maintains that justice is not natural, thereby rejecting the compromise with traditional natural law and wholly returning to the position of Thomas Hobbes. Now, in the original state of nature, Pufendorf's rational principles of natural law cannot be known; later, when they may be known, they are not by nature enforced.

- KEYWORDS: natural law; freedom; morality; sociability.

\section{Referências bibliográficas}

BACHOFEN, B. La condition de la liberté. Rousseau, critique des raisons politiques. Paris: Payot, 2002.

BEHME, T. Samuel Pufendorf: Naturrecht und Staat. Göttingen: Vandenhoeck \& Ruprcht, 1995.

BURLAMAQUI, J.-J. Pricipes du Droit Naturel. Hildesheim: Georg Olms Verlag, 1984.

BRUFAU PRATS, J. La Actitud Metodica de Pufendorf y la Configuracion de la "Disciplina Juris Naturalis". Madrid: I.E.P., 1968.

DERATHÉ, R. Jean-Jacques Rousseau et la science politique de son temps. 2 ed. Paris: Vrin, 1970.

FIORILLO, V. Tra Egoismo e Socialità. Il Giusnaturalismo di Samuel Pufendorf. Napoli: Jovene Editore, 1992.

GAGNEBIN, B. Burlamaqui et le droit naturel. Genève: Éditions de la Frégate, 1944.

GOLDSCHMIDT, V. Anthropologie et politique. Les principes du système de Rousseau. Paris: Vrin, 1974.

GOYARD-FABRE, S. Pufendorf et le droit naturel. Paris: PUF, 1994.

Pufendorf et Grotius: deux faux amis ou la bifurcation philosophique des théories du droit naturel. In V. Fiorillo (org.) Samuel Pufendorf Filosofo del Diritto e della Politica. Atti del Convegno Internazionale. Milano, 11-12 novembre 1994. Napoli: La Città del Sole, 1996, p.171-207.

Os Fundamentos da Ordem Jurídica (trad. de C. Berliner) São Paulo: Martins Fontes, 2002.

HALL, J. C. Rousseau. Cambridge: Schenkman Publishing Company, 1973.

HOBBES, T. Leviathan. Cambridge: Cambridge University Press, 1996.

LENOIR, N. Domination et légitimité. Deux stratégies d'interrogation du politique chez Jean-Jacques Rousseau. Lille: ANRT, 2003.

MASTER, R. D. The Political Philosophy of Rousseau. Princeton. New Jersey: Princeton University Press, 1968.

PALLADINI, F. Samuel Pufendorf Discepolo di Hobbes. Bologna: Il Mulino, 1990. 
PLATTNER, M. F. Rousseau's State of Nature. DeKalb: Northern Illinois University Press, 1979.

PUFENDORF, S. De Officio Hominis et Civis Juxta Legem Naturalem Libri Duo. With an Introduction by Walther Schücking. The photographic reproduction of the edition of 1682. New York: Oxford University Press (The Classics of International Law), 1927.

. Gesammelte Werke. Band 3: Elementa jurisprudentiae universalis. Herausgegeben von Thomas Behme. Berlin: Akademie Verlag, 1999.

Gesammelte Werke. Band 4.1: De jure naturae et gentium (Liber primus - Liber quartus). Herausgegeben von Frank Böhling. Berlin: Akademie Verlag, 1998a.

Gesammelte Werke. Band 4.2: De jure naturae et gentium (Liber quintus - Liber octavus). Herausgegeben von Frank Böhling. Berlin: Akademie Verlag, 1998b.

REALE, M. Le ragioni della politica. J.-J. Rousseau dal Discorso sull'ineguaglianza al Contratto. Roma: Edizioni Dell'Ateneo, 1983.

ROUSSEAU, J.-J. Oeuvres Complètes. Tomo III. Paris: Pléiade, Gallimard, 1964.

SCATTOLA, M. Ordem e imperium: das políticas aristotélicas do começo do século XVII ao direito natural de Pufendorf. In Giuseppe Duso (org.) O Poder. História da Filosofia Política Moderna (trad. de A. Ciacchi, L. C. Silva e G. Tosi). Petrópolis: Editora Vozes, 2005, p.94-110.

TODESCAN, F. Le Radici Teologiche del Giusnaturalismo Laico. Il problema della secolarizzazione nel pensiero giuridico di Samuel Pufendorf. Milano: Giuffrè Editore, 2001.

VILLEY, M. A formação do pensamento jurídico moderno (trad. de C. Berliner). São Paulo: Martins Fontes, 2005.

WELZEL, H. La Dottrina Giusnaturalistica di Samuel Pufendorf. Un contributto alla storia delle idee dei secoli XVII e XVIII. Traduzione italina di Vanda Fiorillo. Torino: G. Giappichelli Editore, 1993. 